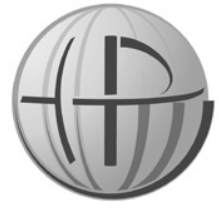

Horyzonty Polityki 2020, Vol. 11, No 35

OPEN ACCESS

\section{KAROL RYSZKOWSKI}

http://orcid.org/0000-0003-2744-3533 Uniwersytet Ekonomiczny w Krakowie ryszkowskikarol@gmail.com

\section{Aleksandra Witoszek-Kubicka}

http://orcid.org/0000-0001-5304-3379

Uniwersytet Ekonomiczny w Krakowie aleksandra.witoszek@uek.krakow.pl

DOI: 10.35765/HP.1932

\title{
Zasadność wprowadzenia prostej spółki akcyjnej do polskiego porządku prawnego
}

\section{Streszczenie}

CEL NAUKOWY: Głównym celem artykułu jest ocena zasadności wprowadzenia prostej spółki akcyjnej (PSA) do polskiego porządku prawnego.

PROBLEM I METODY B ADAWCZE: Podstawową metodę stanowi analiza ustaw dotyczących prostej spółki akcyjnej oraz ich interpretacji prezentowanych przez przedstawicieli doktryny.

PROCES WYWODU: Artykuł składa się z trzech zasadniczych części. W pierwszej została zaprezentowana charakterystyka PSA wraz komentarzami ustawodawcy. W drugiej części podjęto próbę uzasadnienia twierdzenia, że ten typ spółki jest atrakcyjny dla start-upów. W szczególności skupiono się na niekonwencjonalnym rozwiązaniu w zakresie pozyskiwania funduszy na działalność biznesową poprzez finansowanie społecznościowe. Trzecia część przedstawia stanowisko ekspertów dotyczące możliwości wykorzystania tego rodzaju formy prawnej w działalności start-upów, skupiając się na deklarowanych przez ustawodawcę ułatwieniach.

WYNIKI ANALIZY NAUKOWEJ: Dzięki przeprowadzonej analizie ustaw i literatury przedmiotu wskazano potencjalne zalety i wady z wprowadzenia PSA do polskiego porządku prawnego. Autorzy zajmują stanowisko, że połączenie cech spółki z ograniczoną odpowiedzialnością ze spółką akcyjną może stanowić odpowiedź ustawodawcy na zapotrzebowanie środowiska start-upów. Jednoznaczna ocena będzie jednak możliwa dopiero po przetestowaniu tej formy prawnej w praktyce gospodarczej. 
WNIOSKI, INNOWACJE, REKOMENDACJE: Wprowadzenie nowej formy prawnej może znacząco wpłynąć na zainteresowanie finansowaniem społecznościowym. Autorzy uważają jednak, że dopełnieniem nowych rozwiązań prawnych dedykowanych start-upom byłoby doprecyzowanie przepisów w zakresie crowdfundingu udziałowego.

\title{
SŁoWA KLUCZOWE:
}

Crowdfunding, finansowanie start-upów, Prosta Spółka Akcyjna, Prawo spółek, Prawo umów

\author{
Abstract \\ THE LEGITIMACY OF INTRODUCING \\ A SIMPLE JOINT-STOCK COMPANY INTO \\ THE POLISH LEGAL ORDER
}

RESEARCH OBJECTIVE: The main purpose of the article is to assess the legitimacy of introducing a simple joint-stock company (PSA) into the Polish legal order.

THE RESEARCH PROBLEM AND METHODS: The basic method is the analysis of laws regarding a simple joint-stock company and their interpretation presented by representatives of the doctrine.

THE PROCESS OF ARGUMENTATION: The article consists of three main parts. The first presents the characteristics of the PSA together with the legislator's comments. The second part attempts to justify the claim that this type of company is attractive for start-ups. In particular, the focus was on an unconventional solution in the area of raising funds for business operations through crowdfunding. The third part presents the experts' position on the possibility of using this type of legal form in the activities of start-ups focusing on the facilities declared by the legislator.

RESEARCH RESULTS: Due to the analysis of laws and subject literature, potential advantages and disadvantages of introducing PSA into the Polish legal order were indicated. The authors take the view that combining the features of a limited liability company with a joint-stock company may be the legislator's response to the needs of the start-up environment. However, an unambiguous assessment will only be possible after testing this legal form in business practice.

CONCLUSIONS, INNOVATIONS, AND RECOMMENDATIONS: The introduction of a new legal form can significantly affect interest in crowdfunding. However, the authors believe that the complement of new legal 
solutions dedicated to start-ups would be to clarify the regulations on equity crowdfunding.

\section{KeYwORDS:}

Crowdfunding, Startups financing, Simple joint-stock company, Company law, Contract law

\section{WSTĘP}

Ustawą o zmianie ustawy Kodeks spółek handlowych (KSH) oraz niektórych innych ustaw z dnia 19 lipca 2019 r. (Dz.U. z 2019 r. poz. 1655) ustawodawca wprowadził nowy rodzaj spółki do polskiego prawa, to jest prostą spółkę akcyjną (PSA). Ustawą o zmianie ustawy Kodeks postępowania cywilnego oraz niektórych innych ustaw z dnia 13 lutego 2020 r. (Dz.U. z 2020 r. poz. 288) legislator wprowadził kolejne przepisy dotyczące prostej spółki akcyjnej oraz przesunął o rok datę wejścia jej w życie. Prosta spółka akcyjna, mimo że nie weszła jeszcze w życie w dniu 1 marca 2020 roku, cieszy się dużym zainteresowaniem zarówno doktryny, jak i praktyki. Określa się ją też mianem "Spółki dla startupów” (PAP 2020), ze względu na jej cel, którym ma być wspieranie i rozwój tego rodzaju firm w Polsce.

W związku ze wspominanym celem prostej spółki akcyjnej negatywnie zostało przyjęte odłożenie wejścia w życie przepisów regulujących o jeden rok, to jest $\mathrm{z}$ dnia 1 marca 2020 roku na dzień 1 marca 2021 roku. Ministerstwo Rozwoju podało w komunikacie, że przesunięcie wejścia w życie przepisów dotyczących PSA to konsekwencja odroczenia wprowadzenia elektronicznego postępowania rejestrowego (MR 2020). Przepisy te wprowadzają obligatoryjne elektroniczne postępowanie rejestrowe $\mathrm{w}$ zakresie rejestru przedsiębiorców KRS, a więc również prostej spółki akcyjnej. Ponieważ zgodnie z art. 36a pkt 6a ustawy o Krajowym Rejestrze Sądowym, wchodzącym w życie 1 marca 2021 roku, przepisy dotyczące rejestru przedsiębiorców stosuje się do prostych spółek akcyjnych.

Zmiany i odłożenie wejścia w życie prowokują dyskusje na temat zasadności wprowadzenia prostej spółki akcyjnej (PSA) do polskiego porządku prawnego, a ocena tej zasadności jest głównym celem 
tego artykułu. Autorzy wykorzystują w tym celu metodę dogmatyczno-prawną do opisu charakterystyki i oceny regulacji prawnych dotyczących PSA, uzupełniając rozważania informacjami na temat crowdfundingu. Artykuł zawiera analizę motywów przyświecających rządowi w pracach nad nową formą spółki akcyjnej. Opracowanie składa się z trzech zasadniczych części. W pierwszej została zaprezentowana charakterystyka PSA wraz komentarzami ustawodawcy. W drugiej części podjęto próbę uzasadnienia twierdzenia, że ten typ spółki jest atrakcyjny dla start-upów. W szczególności skupiono się na niekonwencjonalnym rozwiązaniu w zakresie pozyskiwania funduszy na działalność biznesową poprzez finansowanie społecznościowe. Trzecia część przedstawia stanowisko ekspertów dotyczące możliwości wykorzystania tego rodzaju formy prawnej w działalności start-upów, skupiając się na deklarowanych przez ustawodawcę ułatwieniach.

Publikacja została dofinansowana ze środków subwencji przyznanej Uniwersytetowi Ekonomicznemu w Krakowie.

\section{CHARAKTERYSTYKA PROSTEJ SPÓŁKI AKCYJNEJ (PSA)}

Według ustawodawcy celem PSA jest ułatwienie innowacyjnym przedsiębiorcom w Polsce zebrania kapitału, założenia i funkcjonowania spółki. Dla działalności tej nieadekwatne są ramy obecnie istniejących spółek handlowych, w szczególności kapitałowych.

Można jednak wskazać wątpliwości w sprawie określenia prostej spółki akcyjnej jako kapitałowej ze względu przejęcie lub znaczne podobieństwo do rozwiązań ze spółek osobowych to jest:

- możliwość wniesienia wkładu niepieniężnego na kapitał inny niż akcyjny do prostej spółki akcyjnej w postaci prawa niezbywalnego lub świadczenia pracy bądź usług (w przypadku spółki z ograniczoną odpowiedzialnością oraz spółki akcyjnej, zgodnie $\mathrm{z}$ art. $14 \S 1$. KSH, jest to w ogóle niemożliwe);

- uproszczona likwidacja, która różni się zarówno od likwidacji przewidzianej tak dla spółek osobowych, jak i kapitałowych, jednak założenia regulacji nawiązują do likwidacji przewidzianej dla spółek osobowych; 
- brak konieczności istnienia rady nadzorczej, o ile nie występuje ona w spółkach osobowych, to w spółce akcyjnej jest ona obligatoryjna, a w spółce z ograniczoną odpowiedzialnością po spełnieniu przesłanek z art. $213 \S 2$. KSH również jest obligatoryjna;

- jedynie formalny obowiązek posiadania kapitału zakładowego, ze względu na symboliczną wysokość obligatoryjną w wysokości 1 złotego.

Odnośnie do wysokości kapitału zakładowego widać tu analogię do francuskiej Uproszczonej Spółki Akcyjnej ((Société par Actions Simplifiée - SAS), gdzie od 2009 roku wynosi on 1 euro oraz słowackiej prostej spółki akcyjnej (Jednoduchá Spoločnost' na Akcie), który również opiewa na 1 euro (Sójka, 2018, s. 15). Ponadto do SAS zostały dopuszczone wkłady niepieniężne w postaci pracy lub usług (Wiórek, 2018, s. 6).

Prosta spółka akcyjna opierać się ma na elastyczności i niskich wymogach dotyczących jej zakładania. Minimalny kapitał zakładowy ustalono na 1 zł, umożliwiono obejmowanie akcji w zamian za świadczenie pracy lub usług na rzecz spółki oraz wprowadzono błyskawiczną 24-godzinną ścieżkę rejestracji online.

Nowością jest także brak konieczności powoływania rady nadzorczej, swoboda w zakresie kształtowania umowy spółki czy uproszczona likwidacja. Wszystko skrojone pod start-upy, które dziś muszą borykać się z piętrzonymi wymogami dotyczącymi prowadzenia choćby spółek z .o.o. (Lis 2020).

Warto zauważyć, że zgodnie z art. 300120 § 1. pkt 2 KSH rozwiązanie spółki powoduje uchwała walnego zgromadzenia o rozwiązaniu spółki albo o przeniesieniu siedziby spółki za granicę, chyba że przeniesienie siedziby ma nastąić do innego państwa członkowskiego Unii Europejskiej lub państwa strony-umowy o Europejskim Obszarze Gospodarczym, a prawo tego państwa to dopuszcza. Mamy więc do czynienia z częściowym odejściem od teorii siedziby oraz pewnym podobieństwem do europejskiego zgrupowania interesów gospodarczych oraz spółki europejskiej. Może to przyczynić się konkurencyjności formy polskiej prostej spółki akcyjnej jako formy dla start-upów na rynku europejskim, a na pewno stanowi udogodnienie dla przedsiębiorców.

Kolejną cechą zbliżającą prostą spółkę akcyjną do prawa europejskiego jest możliwość wyboru między przyjętym w KSH modelem 
dualistycznym (zarząd i rada nadzorcza), a modelem monistycznym (rada dyrektorów). Rozwiązanie to może przyciagnąć inwestorów, w których panuje system monistyczny.

Wedle portalu rządowego korzyści z tej regulacji są następujące (www.biznes.gov.pl, 2020):

- bardzo niski kapitał akcyjny wymagany przy zakładaniu spółki (1 zł);

- elastyczne podejście do organów spółki, w tym możliwość powołania rady dyrektorów, która łączy cechy zarządu i rady nadzorczej;

- prostsze procedury i większa swoboda w podejmowaniu uchwał zdalnie, za pomocą np. poczty elektronicznej czy komunikatorów internetowych;

- większa elastyczność, jeśli chodzi o rodzaje akcji i zasady działania spółki, w tym akcje za pracę lub usługi;

- możliwość założenia przez Internet, w systemie S24 (system umożliwiający elektroniczną rejestrację podmiotów gospodarczych);

- rejestr akcjonariuszy w formie cyfrowej, prowadzony przez notariusza lub biuro maklerskie;

- łatwiejsze dysponowanie środkami spółki - brak „zamrożonego" kapitału zakładowego;

- proste zasady dotyczące likwidacji spółki i krótszy czas potrzebny na likwidację.

Przedstawiony przez Ministerstwo Rozwoju w czerwcu 2016 roku "Zarys koncepcji prostej spółki akcyjnej (PSA)" (MR, 2020) wskazuje na uzasadnienie bytu nowego typu spółki kapitałowej następujące motywy:

Impulsem do rozważania potrzeby wprowadzenia do polskiego porządku prawnego nowego typu spółki kapitałowej była analiza otoczenia prawnego funkcjonowania w Polsce tzw. start-upów, czyli firm innowacyjnych, działających najczęściej w obszarze nowych technologii. Do cech charakterystycznych start-upów zalicza się, w szczególności, niskie koszty rozpoczęcia działalności, wyższe niż w przypadku klasycznych przedsięwzięć ryzyko oraz potencjalnie wyższy zwrot z inwestycji. Główne źródła finansowania tego typu przedsięwzięć to fundusze typu venture, anioły biznesu oraz przybierający na znaczeniu crowdfounding (MR, 2020). 
Wedle uzasadnienia:

Koncepcja Prostej Spółki Akcyjnej zmierza do realizacji następujących, podstawowych celów:

- łatwe założenie spółki (w tym rejestracja elektroniczna);

- minimalne wymogi kapitałowe dla założycieli i możliwość elastycznego kształtowania struktury majątkowej spółki;

- zapewnienie możliwości łatwych i różnorodnych form inwestycji w przedsięwzięcie ( $w$ tym finansowania crowdfundingowego);

- pogodzenie interesów założycieli z atrakcyjnością przedsięwzięcia dla inwestorów poprzez ułatwienie ułożenia relacji między założycielami oraz między założycielami i inwestorami, przy zmniejszeniu ryzyka narzucania założycielom warunków umów inwestorskich czy uregulowanie rozwiązań ułatwiających inwestycje;

- możliwie szybka i nieskomplikowana likwidacja spółki (MR, 2020).

W uzasadnieniu tym wskazano, że zarówno spółka z ograniczona odpowiedzialnością jak i spółka akcyjna nie są odpowiednie dla start-upów.

Brak udziałów niemych, wysokość minimalnej wartości udziału oraz ograniczony już poprzez zmianę art. $180 \mathrm{KSH}$ rygor formy przy zbyciu udziałów to elementy negatywne w spółce z ograniczoną odpowiedzialnością. Stosunkowo drogie i skomplikowane utworzenie spółki akcyjnej (MR, 2020).

Przykładem funkcjonowania prostej spółki akcyjnej, a zarazem wzorem według „Zarysu koncepcji Prostej Spółki Akcyjnej”, jest Francja, gdzie uproszczona spółka akcyjna (SAS) funkcjonuje w systemie prawa spółek od 1994 roku oraz Słowacja, gdzie prosta spółka akcyjna weszła w życie 1 stycznia 2017 roku (MR, 2020). Warto podkreślić, że jedną z zalet prostej spółki akcyjnej jest możliwość jej założenia za pomocą udostępnionego wzorca w systemie teleinformatycznym, tak jak ma to miejsce obecnie w przypadku spółki jawnej, spółki komandytowej oraz spółki z organiczną odpowiedzialnością. Wszystkie wymienione zalety PSA mają skłonić do zakładania w Polsce start-upów w formie prostej spółki akcyjnej oraz stanowić alternatywę dla spółki akcyjnej, która obecnie w Polsce służy także celom crowdfundingowym. 


\section{CROWDFUNDING JAKO ŹRÓDŁO FINANSOWANIA START-UPÓW}

Rozważając praktyczną aplikację uzasadnienia ustawodawcy należy przeanalizować źródła finansowania start-upów, przyjmowane formy prawne i potencjalny wpływ wprowadzenia PSA na możliwości wykorzystania crowdfundingu jako źródła ich finansowania. Początkowy etap działalności, zwany przez autorów fazą start-up, fazą założycielską, fazą rozruchu lub etapem początkowym rozwoju (Kordela, 2018), według autorów dotyczy pierwszych dwóch lub trzech lat działalności przedsiębiorstwa w niektórych przypadkach trwając do siedmiu lat (Poznańska, 2009, s. 179; Timmons and Spinelli, 2007, s. 261). Najczęściej wymieniane w literaturze cechy tego etapu rozwoju przedsiębiorstwa to wysoki potencjał wzrostu (Aronsson, 2004, s. 289-292) i innowacje (Baruk, 2006, s. 94) rozumiane jako wprowadzenie nowego lub ulepszonego produktu lub usługi, procesu lub organizacji. Start-up jest często określany jako organizacja tymczasowa, która szuka powtarzalnego, skalowalnego i rentownego modelu biznesowego (Blank and Dorf, 2013, s. 19). Ta charakterystyka jest podstawą rozważań autorów tego artykułu.

$\mathrm{Na}$ tym etapie zapotrzebowanie na kapitał jest bardzo wysokie. Dostępne źródła finansowania są znacznie ograniczone. Organizacja nie ma jeszcze stabilnej pozycji rynkowej, ryzyko inwestycyjne jest wysokie. Krótkie doświadczenie rynkowe powoduje ograniczoną wiarygodność podmiotu w oczach potencjalnych pożyczkodawców. Na początkowym etapie ryzyko finansowe jest najwyższe, ponieważ jest to okres pierwszej rynkowej weryfikacji projektu inwestycyjnego - jego akceptacji lub odrzucenia przez potencjalnych odbiorców. $\mathrm{Z}$ tego powodu kapitał jest najdroższy i najtrudniejszy do zdobycia. Ważną rolę odgrywają klasyczne źródła finansowania. Jednym ze źródeł, szczególnie na początku istnienia start-upu, jest bootstrapping, tj. finansowanie z własnych oszczędności, z limitu karty kredytowej, pożyczek i tzw. FFF (family, friends, fools) - kapitału pozyskanego od rodziny, przyjaciół i „głupców” (ci, którzy bezrefleksyjnie wierzą w sukces przedsięwzięcia) (Ebben and Johnson, 2006, s. 851-856), co jednak w dużej mierze nie wystarcza do prowadzenia działań, tworząc lukę kapitałową. 
Pierwsza faza działalności przedsiębiorstwa charakteryzuje się bardzo wysokim ryzykiem operacyjnym, a drugiej strony często cechuje się dużym zapotrzebowaniem na kapitał. Na początku rentowność operacyjna firmy jest zwykle niska, a nawet ujemna, przepływy netto również są ujemne. Przedstawione cechy tej fazy pokazuja, że firma ma wysoki popyt na kapitał do finansowania celów dotyczących kluczowych obszarów działalności, takich jak:

- uruchomienie produkcji i prezentacja produktu/usługi na rynku,

- intensywne działania marketingowe,

- stworzenie wstępnej struktury organizacyjnej firmy (Gąsiorowska, 2015, s. 92).

Jednocześnie źródła jego finansowania są znacznie ograniczone. Ze względu na wysokie ryzyko operacyjne i niekorzystne przepływy netto potencjalni wierzyciele nie są zdeterminowani do inwestowania w spółkę. Ze względu na częsty brak zabezpieczeń o wysokiej wartości, a także niską wiarygodność kredytowa, firma może mieć trudności z uzyskaniem kredytu bankowego lub pożyczki na korzystnych warunkach, co zostało potwierdzone w badaniach przeprowadzonych przez Siti F. Hazudinę i innych (Hazudin, Kader, Tarmuji, Ishak, Ali, 2015, s. 436-443), a także Thorstena Becka i Asli Demirguc-Kunta (Beck and Demigruc-Kunt, s. 2931-2943). Oprócz klasycznych źródeł finansowania, źródła takie jak crowdfunding, anioły biznesu i kapitał podwyższonego ryzyka, a także dotacje z funduszy UE są wymieniane jako stosunkowo łatwo dostępne na tym etapie istnienia firmy (Zwilling, 2020). Venture capital i private equity to fundusze, które stwarzają możliwości finansowania korzystne dla przedsiębiorstwa, ponieważ nie zmniejszają płynności finansowej jednostki. Organizacja nie płaci kosztów podatku dochodowego na bieżąco, a fundusz często wspiera przedsiębiorstwo wiedzą. Jest bezpośrednio zaangażowany w ryzyko związane z niepowodzeniem przedsięwzięcia i zainteresowany wzrostem jego wartości, dlatego wykazuje znaczące zaangażowanie (Ostaszewski, 2000, s. 23-24). Anioły biznesu to jedno $\mathrm{z}$ niewielu źródeł finansowania, które często jest przeznaczone na nowe przedsięwzięcia, obarczone wysokim ryzykiem i mające trudności z uzyskaniem środków z tradycyjnych źródeł finansowania. Oprócz kapitału aniołowie biznesu zwykle dzielą się swoją wiedzą i doświadczeniem oraz siecią kontaktów (Argerich and Cruz-Cázares, 2017, s. 310-330). 
Usystematyzowane, dostępne wg literatury przedmiotu, źródła finansowania $\mathrm{w}$ zależności od etapu rozwoju organizacji zostały przedstawione na rys. 1 .

Rys. 1. Źródła finansowania a etap rozwoju przedsiębiorstwa

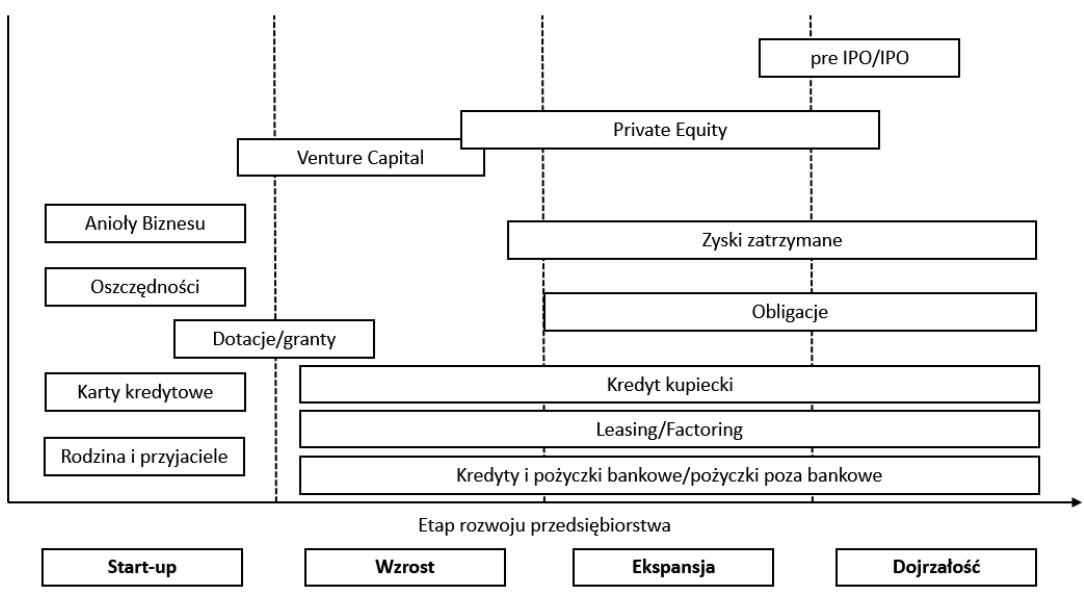

Źródło: opracowanie własne na podstawie „Polskie Start-upy. Raport 2018”, www. pfr.pl , http://www.innowacyjnypomysl.eu/poradnik-rozdzial-pierwszy

Finansowanie społecznościowe lub dosłownie finansowanie tłumem; z połączenia słów tłum i finansowanie to zjawisko gromadzenia funduszy na realizację projektu za pomocą wirtualnej społeczności. Według definicji finansowanie społecznościowe to system, który pozwala inwestować $\mathrm{w}$ różne projekty i przedsięwzięcia, często za pomocą niskich kwot i przy użyciu platform internetowych, które umożliwiają kontakt między osobą zbierającą środki i inwestującą w projekt (Agrawal, Catalini and Goldfarb, 2011, s. 4). Istnieją trzy podstawowe modele finansowania społecznościowego (Dziuba, 2015, s. 23-24):

- Crowdfunding dotacyjny (donation-based crowdfunding),

- Crowdfunding dłużny (crowdlending, sociallending, peer-to-peer lending),

- Crowdfunding udziałowy (crowdinvesting, equity crowdfunding). Model dotacyjny jest najbardziej rozpowszechniony w Polsce. W swoim klasycznym podejściu dawca nie ma żadnych korzyści. Istnieje jednak podrodzaj tego modelu, w ramach którego osoby 
wspierające otrzymują gratyfikację niefinansową za wypłatę określonej kwoty, zazwyczaj gratyfikacja ma znacznie niższą wartość niż płatność dawcy. Jest to model, na którym oparte są platformy, takie jak Kickstarter.com, Rockethub.com lub Indiegogo.com. Istnieje również podrodzaj określany jako przedsprzedaż. Finansujący wspierają tworzenie produktu, który jest im następnie sprzedawany po niższej cenie lub otrzymują go wyłącznie za przedpłatę.

Model kredytowy pozwala pożyczać pieniądze z pominięciem tradycyjnych instytucji finansowych. W ramach tego modelu można wyróżnić model mikropożyczek i model pożyczek społecznych.

Model inwestycyjny daje możliwość pozyskania kapitału poprzez ulokowanie przez inwestora wolnych środków finansowych w przedsiębiorstwach w celu osiągnięcia korzyści finansowych. Wyróżnia się kilka podrodzajów tego modelu, w których inwestuje się w (Dziuba, 2015, s. 23-24):

- zakup akcji,

- zakup innych papierów wartościowych,

- działania społeczne (papiery wartościowe emitowane w celu finansowania projektów skierowanych do społeczności lokalnej),

- nieruchomości,

- zakup faktur i innych zobowiązań firmy,

- twórczość, oparty na tantiemach model inwestycyjny dla bitcoinów i innych kryptowalut,

- funduszinwestycyjny oparty na finansowaniu społecznościowym. Model hybrydowy (mieszany) jest kombinacją wszystkich lub części wcześniej wymienionych modeli.

Ze względu na potrzeby artykułu szczególna uwaga została poświęcona modelowi inwestycyjnemu. Analiza literatury wskazuje, że finansowanie społecznościowe inwestycyjne jest szczególnie atrakcyjne dla przedsiębiorstw, zwłaszcza w fazie rozruchu (Piekunko-Mantiuk, 2016, s. 41-51). Wspierający nie tylko zapewniają fundusze na rozwój przedsiębiorstwa. Często stają się klientami, a także promują produkt, zwłaszcza gdy uczestniczą w podziale dochodów. W przeciwieństwie do aniołów biznesu lub funduszy venture capital nie mają istotnego wpływu na decyzje biznesowe. Kolejną zaletą finansowania społecznościowego w porównaniu z innymi formami finansowania jest to, że odległość geograficzna między przedsiębiorcą a inwestorem nie odgrywa żadnej roli. Finansowanie 
społecznościowe $\mathrm{w}$ naturalny sposób pozwala na weryfikację produktu i zainteresowania klientów dzięki interakcji z tłumem. Sama kampania zbierania funduszy może być również traktowana jako kampania marketingowa. Nie dziwi więc, że najczęściej korzysta $\mathrm{z}$ niego firma $\mathrm{w}$ początkowej fazie rozwoju. W Polsce istnieją również inicjatywy mające na celu promowanie finansowania społecznościowego jako formy finansowania. W 2017 roku została podpisana umowa między GPW a platformą Beesfund w celu stworzenia wspólnej platformy promującej polskie start-upy (Szopa, 2018, s. 181). W 2016 roku wprowadzono zmiany prawne umożliwiające zbycie akcji przez Internet w systemie S24 (Mizińska, Chudzik-Marczewska), ale tylko dla spółki z ograniczoną odpowiedzialnością. Z drugiej strony model inwestycyjny wciąż nie jest popularny w Polsce. Według badań tylko $2 \%$ polskich start-upów wskazuje finansowanie społecznościowe jako źródło finansowania, jednak $11 \%$ ankietowanych podmiotów deklaruje zamiar pozyskania kapitału poprzez takie finansowanie w ciągu najbliższych 6 miesięcy (Polskie Start-upy 2018).

Jednym z powodów może być sceptyczne podejście inwestorów do projektów. Ze względu na niewielką liczbę polskich portali crowdfundingowych, działających w modelu inwestycyjnym, inwestorzy mają ograniczone możliwości informacyjne w zakresie wiarygodności portalu, określania stopy zwrotu lub ryzyka inwestycyjnego. Istnieje również niewielka świadomość przedsiębiorców na temat tej formy finansowania. $Z$ drugiej strony rozwój rynku finansowania społecznościowego $w$ innych krajach wskazuje na znaczące perspektywy jego ekspansji także w Polsce. Brak odpowiednich regulacji prawnych dotyczących bezpośrednio tej formy finansowania jest obecnie wskazywany jako czynnik hamujący rozwój crowdfundingu w Polsce. Prosta Spółka Akcyjna wydaje się odpowiadać na część wyzwań związanych z finansowaniem poprzez crowdfunding udziałowy w Polsce. Przede wszystkim pozwala na rejestrację elektroniczną, a także ma niskie minimalne wymogi kapitałowe dla założycieli. Atrakcyjna dla start-upów wydaje się także deklarowana przez ustawodawcę możliwie szybka i nieskomplikowana likwidacja spółki. 


\section{ANALIZA POGLĄDÓW PRZEDSTAWICIELI DOKTRYNY DOTYCZĄCYCH ROZWIĄZAŃ PROPONOWANYCH W RAMACH PSA}

Dla oceny zasadności wprowadzenia PSA do polskiego porządku prawnego należy wskazać na opinie przedstawicieli doktryny, które są rozbieżne, jednak pomocne dla ustawodawcy w razie konieczności zmian przepisów dotyczących PSA. Aleksander Kappes wskazuje, że oczekiwania twórców start-upów dotyczą przede wszystkim sfery prawa publicznego, a nie kwestii nowego typu spółki (Kappes, 2018, s. 12), tym samym pokazując niecelowość konstrukcji PSA poprzez złe założenie Ministerstwa Rozwoju. Autor ten wskazuje dalej, że nie ma potrzeby na wprowadzenie nowego typu spółki dedykowanej start-upom (Kappes, 2018, s. 12). O ile można by rozważyć zmiany w prawie publicznym, to i tak, jak wykażę dalej, w polskim systemie spółek brakuje hybrydowej spółki kapitałowej. Jego wątpliwości odnośnie do braku zrównoważenia interesów spółki i wierzycieli w PSA podziela Joanna Kruczalak-Jankowska (Kruczalak-Jankowska, 2018, s. 28). Również Paulina. Dzierżak pozostaje sceptyczna odnośnie do PSA.

Dobrze, że ministerstwo dostrzegło wady istniejącej regulacji prawa spółek. Nasuwa się jednak pytanie, czy właściwym sposobem przeprowadzenia reformy jest mnożenie form prawnych, a nie próba udoskonalenia już istniejących typów spółek? Utworzenie PSA nie wydaje się być właściwym sposobem likwidacji problemów przedsiębiorców. Przedstawienie koncepcji nowej spółki powinno natomiast przyczynić się do wznowienia dyskusji nad zasadnością wprowadzenia nowych rozwiązań do polskiego prawa spółek w ramach istniejących form prawnych, przede wszystkim spółki z o.o. (Dzierżak, 2016, s. 38).

Natomiast Piotr M. Wiórek krytykując PSA, postuluje uelastycznienie przepisów dotyczących spółki z ograniczoną odpowiedzialnością (Wiórek, 2018, s. 6). Przeciwny jest temu zwolennik PSA Tomasz Sójka, który wskazuje, że:

Słusznym założeniem projektodawcy jest „uniknięcie jakiejkolwiek formy destabilizacji obrotu dla tych przedsięwzięć, które do dziś z powodzeniem korzystają z tradycyjnej formy spółki z o.o.". Stosunkowo szybkie wprowadzenie potrzebnych dla technologicznych spółek 
zmian do przepisów o spółce z o.o. wymagałoby wprowadzenia daleko posuniętej wielowariantowości w ramach konstrukcji tej spółki. $\mathrm{W}$ istocie rzeczy doprowadziłoby to do funkcjonowania w obrocie dwóch bardzo różnych typów spółki z o.o. Być może więc prostszym i trafniejszym rozwiązaniem jest wprowadzenie nowej formy spółki. (Sójka, 2018, s. 15).

Można zgodzić się z tym poglądem, gdyż wprowadzona przez modyfikację spółki z o.o. jej wielowariantowość doprowadziłaby do wielu problemów praktycznych oraz niejako „zatarcia” tego typu spółki, problemu z identyfikacją poszczególnej spółki tego rodzaju i zasad jej funkcjonowania w obrocie. Adam Opalski wskazuje, że PSA jest konsekwencją historycznej ewolucji polskiego prawa spółek oraz potrzeb uczestników obrotu gospodarczego (Opalski 2019). Właśnie te potrzeby służą za uzasadnienie przepisów regulujących PSA. Rozwiązania dotyczące PSA - wprowadzone do KSH - zdają się odpowiadać potrzebom praktyki, choć dopiero czas pokaże, jak będą funkcjonowały w praktyce.

Umiejscowienie przepisów regulujących prostą spółkę akcyjną w Dziale Ia Prosta spółka akcyjna, art. $300^{1} \mathrm{KSH}$ do art. $300^{134} \mathrm{KSH}$, to jest pomiędzy spółką z ograniczoną odpowiedzialnością a spółką akcyjną, wskazuje na zamysł ustawodawcy odnośnie do określenia cech tej spółki, a jednocześnie niszy, którą ma zająć w systemie prawa. Jest to zgodne z "Zarysem koncepcji Prostej Spółki Akcyjnej”, wedle którego PSA ma połączyć zalety spółki z ograniczoną odpowiedzialnością i spółki akcyjnej (MR, 2020). Z drugiej jednak strony regulacja prostej spółki akcyjnej może powodować pewne wątpliwości, m.in. natury systemowej. Zgodnie z obowiązującą wersją art. $14 \S 1 \mathrm{KSH}$ : „§1. Przedmiotem wkładu do spółki kapitałowej nie może być prawo niezbywalne lub świadczenie pracy bądź usług".

Nasuwa się pewna analogia do spółki komandytowo-akcyjnej, która również jest spółką hybrydową łączącą cechy spółki kapitałowej - spółki akcyjnej oraz spółki osobowej - spółki jawnej. Jest to expressis verbis wyrażone $\mathrm{w}$ art. $126 \S 1 \mathrm{KSH}$. Można więc uznać, że ustawodawca poprzez unormowanie prostej spółki akcyjnej uzupełnił system spółek o brakujący typ hybrydowy w spółkach kapitałowych, a więc niejako "domknął” system.

Na pewne podobieństwa w zakresie hybryd zwrócono uwage w doktrynie: 
Możliwość wnoszenia wkładu pracy i usług do PSA należy rozumieć jako wprowadzenie pierwiastka osobowego do struktury spółki kapitałowej, podobnie jak np. pierwiastkiem kapitałowym jest członkostwo komandytariusza w spółce komandytowej jako spółce osobowej. Nawet silnie personalistycznie ukształtowana PSA zachowuje co najmniej cechy wyłączenia osobistej odpowiedzialności akcjonariuszy za zobowiązania spółki powierzenia prowadzenia spraw spółki wybieralnemu organowi zarządzającemu (Opalski, 2019).

Należy dodać, że pierwiastkiem kapitałowym jest również członkostwo akcjonariusza w spółce komandytowo-akcyjnej jako spółce osobowej. A. Opalski wskazuje na kapitałowe cechy prostej spółki akcyjnej, które powodują, że należy zaliczyć ją do spółek kapitałowych. Ponadto należy wskazać, że jedną z różnic w porównaniu do drugiej spółki hybrydowej, to jest spółki komandytowo-akcyjnej, jest brak komplementariusza, czyli wspólnika, który odpowiada bez ograniczenia za zobowiązania spółki, a więc elementu stricte osobowego.

\section{ZAKOŃCZENIE}

Zgodnie z Raportem Fundacji Startup Poland za rok 2018 formą prawną polskich start-upów w 72\% jest spółka z ograniczoną odpowiedzialnościa, a spółka akcyjna jedynie w 4\%. W 18\% jest to jednoosobowa działalność gospodarcza, a zaledwie $6 \%$ to inne formy prawne (Beauchamp, Krysztofak-Szopa, Skala, 2018, s. 58). Wskazuje to z jednej strony na zdecydowaną przewagę spółki z ograniczoną odpowiedzialnością nad spółką akcyjną, co może być spowodowane stosunkowo niską wysokością kapitału zakładowego. Jednak aż w 76\% wybierana jest forma spółki kapitałowej. Połączenie cech spółki z ograniczoną odpowiedzialnością ze spółką akcyjną może stanowić odpowiedź ustawodawcy na zapotrzebowanie środowiska start-upów.

Czerpanie ze wzorców francuskich może okazać się trafionym pomysłem, gdyż SAS już od początku funkcjonowania cieszy się dużą popularnością, a wprowadzenie nowej formy prawnej skutkowałoby szybkim zmniejszeniem zainteresowania przedsiębiorców francuską spółką z o.o. (SARL). Można przewidywać podobną tendencję w Polsce ze względu na przyjęcie podobnych rozwiązań w regulacji PSA. 
Bazując na analizie opisu charakterystyki spółki i przedstawionych ocenach regulacji prawnych dotyczących PSA można stwierdzić, że przyjęty projekt i jego uzasadnienie wydaje się poprognozować optymistycznie oraz stanowić odpowiedź na zapotrzebowanie środowiska start-upów. Jednak to przyszłość - wejście w życie ustawy - pokaże, jak PSA przyjmie się w praktyce i czy rzeczywiście ułatwi zakładanie i finansowanie początkowej działalności w Polsce.

\section{Bibliografia}

Agrawal, A., Catalini, C., Goldfarb, A. (2011). The Geography of Crowdfunding. National Bureau of Economic Research working paper, 16820.

Argerich, J., Cruz-Cázares, C. (2017). Definition, Sampling and Results in Business Angels' Research: Toward a Consensus. Management Decision, 55. DOI: https://doi.org/10.5465/AMLE.2004.14242224

Aronsson, M. (2004). Education Matters - but Does Entrepreneurship Education? An Interview with David Birch. Academy of Management Learning \& Education, 3(3).

Baruk, J. (2006). Zarządzanie wiedza i innowacjami. Toruń: Wydawnictwo Adam Marszałek.

Beauchamp, M., Krysztofak-Szopa, J., Skala, A. (2018). Polish Startups 2018 Report. https://drive.google.com/file/d/1eeofGRVryyuwMui EMdBM_YblMCz5CjNG/view.

Beck, T., Demirguc-Kunt, A. (2006). Small and Medium-Size Enterprises: Access to Finance as Growth Constraint. Journal of Banking $\mathcal{E}$ Finance, 30(11). DOI: https://doi.org/10.1016/j.jbankfin.2006.05.009.

Blank, S., Dorf, B. (2013). Podręcznik startupu. Budowa wielkiej firmy krok po kroku. Gliwice: Wydawnictwo Helion.

Dzierżak, P. (2016). Prosta Spółka Akcyjna - mnożenie bytów ponad potrzebę czy właściwe remedium na problemy przedsiębiorców? Monitor Prawa Handlowego, 2.

Dziuba, D.T. (2015). Ekonomika Crowdfundingu. Zarys Problematyki Badawczej. Warszawa: Difin.

Ebben, J., Johnson, A. (2006). Bootstrapping in Small Firms: An Empirical Analysis of Change Over Time. Journal of Business Venturing, 21. DOI: https://doi.org/10.1016/j.jbusvent.2005.06.007.

Gąsiorowska, E. (2015). Sposoby finansowania grupy msp a cykl życia organizacji na rynku. Zeszyty Naukowe PWSZ w Płocku. Nauki Ekonomiczne, XXI. 
Hazudin, S., Kader, M., Tarmuji, N., Ishak, M., Ali, R. (2015). Discovering Small Business Startup Motives, Success Factors and Barriers: A Gender Analysis. Procedia Economics and Finance, 31. DOI: https:// doi.org/10.1016/S2212-5671(15)01218-6.

Kappes, A. (2018). Prosta spółka akcyjna - czy rzeczywiście prosta i czy potrzebna? Uwagi do projektu nowelizacji Kodeksu spółek handlowych, wprowadzającego prostą spółkę akcyjną (projektowane art. 3001-300121 k.s.h.). Przeglad Prawa Handlowego, 5.

Kordela, D. (2018). The use of crowdfunding in financing the early stages of enterprise development. W: A. Pluszyńska, A. Szopa (eds.), Crowdfunding w Polsce. Kraków: Wydawnictwo Uniwersytetu Jagiellońskiego

Kruczalak-Jankowska, J. (2018). Prosta spółka akcyjna - polską superspółką. Przeglad Prawa Handlowego, 9.

Lis, M. Prosta spótka akcyjna z poślizgiem. Posłowie opóźniaja dobra zmiane dla startupów. https://businessinsider.com.pl/firmy/przepisy/prosta-spolka-akcyjna-od-2021-roku-branza-boi-sie-kolejnych-przesuniec/ cbf52dh.

Mizińska, J., Chudzik-Marczewska, M. Zawarcie umowy sprzedaży udziatów przez S24 - instrukcja. https://gm-legal.pl/2019/10/09/zawarcie -umowy-sprzedazy-udzialow-przez-s24-instrukcja/.

Ostaszewski, J. (2000). Źródła pozyskiwania kapitatu przez spótkę akcyjna. Wydawnictwo: Difin.

Piekunko-Mantiuk, I. Crowdfunding jako źródło finansowania start-upów oraz małych i średnich przedsiębiorstw. Przedsiębiorczość i zarzadzanie, 7.

Poselskie poprawki przesuwają o rok wejście wżycie ustawy dot. Prostej Spótki Akcyjnej. http://centrumprasowe.pap.pl/cp/pl/news/info/152410,25,mr-poselskie-poprawki-przesuwaja-o-rok-wejscie-w-zycie-ustawy-dot -prostej-spolki-akcyjnej-(komunikat.

Poznańska, K. (2009). Wzrost i rozwój przedsiębiorstwa. W: I. Lichniak (Ed), Nauka o przedsiębiorstwie. Wybrane zagadnienia. Warszawa: Szkoła Główna Handlowa w Warszawie.

Prosta spótka akcyjna - nowa forma prowadzenia dziatalności. https://www.biznes.gov.pl/pl/firma/zakladanie-firmy/chce-zalozyc-prosta-spolke-akcyjna/prosta-spolka-akcyjna-nowa-forma -prowadzenia-dzialalnosci.

Sójka, T. (2018). O potrzebie zmian unormowań niepublicznych spółek kapitałowych - uwagi na kanwie projektu przepisów o prostej spółce akcyjnej. Przeglad Prawa Handlowego, 9.

Spótka dla startupów staje sie faktem. Jest podpis prezydenta. https://businessinsider.com.pl/firmy/prosta-spolka-akcyjna-dla-startupow-podpis-prezydenta/zn42ykt?utm_source=businessinsider.com. 
pl_viasg_businessinsider\&utm_medium=referal\&utm_campaign=leo_automatic\&srcc=ucs\&utm_v=2.

Szopa A. (2018). Charakterystyka modeli i platform crowdfundingowych w Polsce. W: A. Pluszyńska, A. Szopa (Eds.), Crowdfunding w Polsce. Kraków: Wydawnictwo Uniwersytetu Jagiellońskiego.

Timmons, J.A., Spinelli, S. (2007). New Venture Creation. Entrepreneurship for the 21st Century, Seventh Edition. McGraw - Hill International Edition.

Wiórek, P.M. (2018). O braku potrzeby wprowadzenia prostej spółki akcyjnej (PSA) z perspektywy prawnoporównawczej. Przeglad Prawa Handlowego, 5.

Zarys koncepcji Prostej Spółki Akcyjnej. http://mr.bip.gov.pl/prekonsultacje/prekonsultacje-prosta-spolka-akcyjna.html.

Zwilling, M. (2015). 7 Seed-Stage Funding Sources That Might Finance Your Startup. www.entrepreneur.com/article/250921, 03.03.2020.

\section{Copyright and License}

This article is published under the terms of the Creative Commons Attribution - NoDerivs (CC BY- ND 4.0) License http://creativecommons.org/licenses/by-nd/4.0/ 